\title{
Investigating the Factors Affecting the Ionic Conduction in Nanoconfined $\mathrm{NaBH}_{4}$
}

\author{
Xiaoxuan Luo ${ }^{1}$, Aditya Rawal ${ }^{2}$ and Kondo-Francois Aguey-Zinsou ${ }^{1, *(\mathbb{D}}$ \\ 1 HERC and MERLin, School of Chemical Engineering, The University of New South Wales, \\ Sydney, NSW 2052, Australia; xiaoxuan.luo@student.unsw.edu.au \\ 2 NMR Facility, Mark Wainwright Analytical Centre, The University of New South Wales, \\ Sydney, NSW 2052, Australia; a.rawal@unsw.edu.au \\ * Correspondence: f.aguey@unsw.edu.au
}

check for updates

Citation: Luo, X.; Rawal, A.;

Aguey-Zinsou, K.-F. Investigating the Factors Affecting the Ionic Conduction in Nanoconfined $\mathrm{NaBH}_{4}$. Inorganics 2021, 9, 2. https://doi.org/10.3390/ inorganics 9010002

Received: 28 November 2020 Accepted: 23 December 2020 Published: 1 January 2021

Publisher's Note: MDPI stays neutral with regard to jurisdictional clai$\mathrm{ms}$ in published maps and institutional affiliations.

Copyright: (C) 2021 by the authors. Licensee MDPI, Basel, Switzerland. This article is an open access article distributed under the terms and conditions of the Creative Commons Attribution (CC BY) license (https:// creativecommons.org/licenses/by/ $4.0 /)$.

\begin{abstract}
Nanoconfinement is an effective strategy to tune the properties of the metal hydrides. It has been extensively employed to modify the ionic conductivity of $\mathrm{LiBH}_{4}$ as an electrolyte for $\mathrm{Li}$-ion batteries. However, the approach does not seem to be applicable to other borohydrides such as $\mathrm{NaBH}_{4}$, which is found to reach a limited improvement in ionic conductivity of $10^{-7} \mathrm{~S} \mathrm{~cm}^{-1}$ at $115^{\circ} \mathrm{C}$ upon nanoconfinement in Mobil Composition of Matter No. 41 (MCM-41) instead of $10^{-8} \mathrm{~S} \mathrm{~cm}^{-1}$. In comparison, introducing large cage anions in the form of $\mathrm{Na}_{2} \mathrm{~B}_{12} \mathrm{H}_{12}$ naturally formed upon the nanoconfinement of $\mathrm{NaBH}_{4}$ was found to be more effective in leading to higher ionic conductivities of $10^{-4} \mathrm{~S} \mathrm{~cm}^{-1}$ at $110^{\circ} \mathrm{C}$.
\end{abstract}

Keywords: sodium borohydrides; nanoconfined; ionic conductivity; solid-state electrolyte

\section{Introduction}

The development of solid-state electrolytes is critical for the advancement of all solidstate high-energy density batteries. In this respect, several families of inorganic solid-state electrolytes have been intensively investigated because of their non-flammability and capability in leading to a high $\mathrm{Li}^{+} / \mathrm{Na}^{+}$transference number and thus safety with extended battery life-time [1]. However, current solid-state electrolytes still suffer from low ionic conductivity [2]. Current materials reported to lead to high ionic conductivity are oxide solid-state electrolytes like $\mathrm{La}_{0.52} \mathrm{Li}_{0.35} \mathrm{TiO}_{2.96}$ (ionic conductivity of $10^{-3}$ at room temperature) [3]. However, in this case, the poor contact between the electrode and the ceramic electrolyte causes a high interfacial resistance [4]. Sulfide-based solid-state electrolytes have also been found to lead to high ionic conductivity (e.g., $\mathrm{Li}_{9.54} \mathrm{Si}_{1.74} \mathrm{P}_{1.44} \mathrm{~S}_{11.7} \mathrm{C}_{10.3}$ has an ionic conductivity of $2.5 \times 10^{-2} \mathrm{~S} \mathrm{~cm}^{-1}$ at room temperature) [5], and this is comparable to the ionic conductivity of organic electrolytes [6]; however, sulfide electrolytes have a narrow electrochemical stability window and tend to decompose upon operation and release toxic $\mathrm{H}_{2} \mathrm{~S}$ gas $[7,8]$.

Recently, metal borohydrides have drawn considerable interest because of their chemical and electrochemical stability, as well as chemically compatibility with Li/Na metal [9], but modifications are needed to enable high ionic conductivity [10] in complex borohydrides at ambient and not high temperatures. To date, the most common strategies to tailor the ionic conductivity of complex borohydrides are based on anionic substitution [11-13] or nanoconfinement approaches [10,14]. For example, partial anionic substitution of $\mathrm{BH}_{4}{ }^{-}$by $\mathrm{NH}_{2}$ in $\mathrm{NaBH}_{4}$ leads to an increase in ionic conductivity from $1 \times 10^{-9}$ to $2 \times 10^{-6} \mathrm{~S} \mathrm{~cm}^{-1}$ at $26{ }^{\circ} \mathrm{C}$ [11]. Nanoconfining $\mathrm{LiBH}_{4}\left(\mathrm{LiBH}_{4} @ \mathrm{MCM}-41\right)$ within the pores of ordered silica scaffolds such as MCM-41 was reported to lead to a high ionic conductivity of $0.2 \mathrm{mS} \mathrm{cm}^{-1}$ at $55^{\circ} \mathrm{C}$ instead of $1 \times 10^{-8} \mathrm{~S} \mathrm{~cm}^{-1}$ [10] owing to the interface interaction between $\mathrm{LiBH}_{4}$ and MCM-41 $[15,16]$. Further testing of such a material showed that nanoconfined $\mathrm{LiBH}_{4}$ in an $\mathrm{Li} / \mathrm{S}$ cell could deliver a high capacity of $1220 \mathrm{mAh} \mathrm{g}^{-1}$ at a working voltage of $2 \mathrm{~V}$ and 
at $0.03 \mathrm{C}$ rates for 40 cycles, which is comparable to the sulfide electrolytes $[17,18]$. To date, such improvements have only been reported for $\mathrm{LiBH}_{4}$, with no report on the possibility of such an observation to other borohydrides and in particular $\mathrm{NaBH}_{4}$, which is of interest as a solid electrolyte for $\mathrm{Na}$ batteries. Except for borohydrides materials, nanoconfinement has been proven as an effective method to tailor the ionic conductivity of electrolyte materials including solid composite polymer electrolytes and ionic liquid electrolytes confined in Metal Organic Frameworks [19-21]. Herein, we report on the successful confinement of $\mathrm{NaBH}_{4}$ into the MCM-41, and the resulting limited improvement in ionic conductivity. As a reference, $\mathrm{LiBH}_{4}$ was also confined into the scaffold material MCM- 41 and the existence of an oxide phase in $\mathrm{LiBH}_{4} @ \mathrm{MCM}-41$ further proved our hypothesis, i.e., the strong oxidation of $\mathrm{NaBH}_{4}$ upon nanoconfinement in MCM-41 and thus the formation of an extensive oxide phase at the borohydride/MCM- 41 interface limits $\mathrm{Na}$ and Li conduction. Better improvement in ionic conductivity could be achieved by partially decomposing $\mathrm{NaBH}_{4}$ into a mixture of $\mathrm{Na}_{2} \mathrm{~B}_{12} \mathrm{H}_{12}$ and $\mathrm{NaBH}_{4}$.

\section{Results and Discussions}

\subsection{Infiltration of $\mathrm{NaBH}_{4}$ in $\mathrm{MCM}-41$}

To confirm the degree of infiltration of $\mathrm{NaBH}_{4}$ into MCM-41, Brunauer-EmmettTeller (BET) measurements were carried out. As expected, melt infiltration of $\mathrm{NaBH}_{4}$ into MCM-41 resulted in a pore volume reduction from the original MCM-41 value of 1.02 to $0.02 \mathrm{~cm}^{3} \mathrm{~g}^{-1}$, and this corresponded to a $78 \%$ pore filling. As reflected by BET, the melt infiltration of $\mathrm{NaBH}_{4}$ into MCM-41 also led to a significant decrease of the surface area of $\mathrm{NaBH}_{4} @ \mathrm{MCM}-41$ from $1110.91 \mathrm{~m}^{2} \mathrm{~g}^{-1}$ for pristine MCM- 41 to $3.5 \mathrm{~m}^{2} \mathrm{~g}^{-1}$ (Table S1 and Figure S1).

Further analysis by transmission electron microscopy (TEM) showed that the ordered porous structure of MCM- 41 was filled upon nanoconfinement of $\mathrm{NaBH}_{4}$ with the disappearance of a clear porous structure (Figure S2a). Additionally, elemental mapping showed a signal of $\mathrm{Na}$ and $\mathrm{Si}$ overlapping, and this was taken as additional evidence that $\mathrm{NaBH}_{4}$ was melt infiltrated within the porosity of MCM-41 (Figure S3).

$X$-ray diffraction (XRD) patterns of the pristine and nanoconfined $\mathrm{NaBH}_{4}$ are shown in Figure 1a. For $\mathrm{NaBH}_{4} @ \mathrm{MCM}-41$, all the peaks are assigned to $\mathrm{NaBH}_{4}$, which indicates that no detectable additional phase was formed during the melt infiltration process at $560^{\circ} \mathrm{C}$. However, all the diffraction peaks showed a significant boarding and shift to lower diffraction angles as compared with pristine $\mathrm{NaBH}_{4}$ (Figure 1 b), which suggested some confinement of the borohydride [22-24]. Indeed, a shift has been reported to occur for confined borohdyrides owing to the lattice strain imposed by the MCM-41 scaffold [22,25], as further revealed by the small angle X-ray diffraction analysis of MCM-41 and $\mathrm{NaBH}_{4} @ \mathrm{MCM}-41$. As shown in Figure 1c, the main (100) diffraction peak of MCM-41 broadens. This peak also shifted to higher diffraction angles, further indicating that $\mathrm{NaBH}_{4}$ was located within the internal pore of MCM-41 [26]. From these results, it can thus be concluded that $\mathrm{NaBH}_{4}$ is infiltrated within the porosity of MCM-41. Another indirect evidence of the nanoconfinement is the shift in the dehydrogenation peak of $\mathrm{NaBH}_{4}$ upon infiltration in MCM-41, from 550 to $520^{\circ} \mathrm{C}$ (Figure S4).

To further determine any amorphous phases that may have formed during the nanoconfinement of $\mathrm{NaBH}_{4}$ in MCM- 41 at $560^{\circ} \mathrm{C}$, Fourier Transform Infrared Spectrometery (FTIR)and nuclear magnetic resonance (NMR) analyses were carried out. By FTIR (Figure 2), the typical $\mathrm{BH}$ stretching and bending vibrations corresponding to the $\mathrm{BH}_{4}{ }^{-}$anion in $\mathrm{NaBH}_{4}$ were observed in $\mathrm{NaBH}_{4} @ \mathrm{MCM}-41$ in the range from 2400 to $2200 \mathrm{~cm}^{-1}$ and at $1091 \mathrm{~cm}^{-1}$, in agreement with previous reports [27]. The broad peaks between 3800 and $3200 \mathrm{~cm}^{-1}$ were assigned to $\mathrm{OH}$ stretching modes corresponding to a partial oxidation of $\mathrm{NaBH}_{4}$ in contact with the walls of the MCM-41. As a scaffold material, MCM-41 possesses silanol $(\mathrm{Si}-\mathrm{OH})$ and hydrogen-bonded terminal hydroxyl (Si-OH-O-Si) groups located within its internal structure [28]. Therefore, during the melt infiltration of $\mathrm{NaBH}_{4}$, it is not surprising that silanol and/or hydroxyl groups readily react with $\mathrm{NaBH}_{4}$ to lead to the 
formation of boron oxide phases in $\mathrm{NaBH}_{4} @ \mathrm{MCM}-41$, as evidenced by the peaks at 1626 , 883 , and $794 \mathrm{~cm}^{-1}$ owing to the $\mathrm{B}-\mathrm{O}$ vibrational modes (Figure 2) [29-31]. To eliminate the concern regarding the formation of other oxide compounds (e.g., $\mathrm{NaO}_{2}$ ), we carefully checked the FTIR spectrum of $\mathrm{NaBH}_{4} @ \mathrm{MCM}-41$ in the range of $800-400 \mathrm{~cm}^{-1}$ (Figure S8), and the only peak located at $473 \mathrm{~cm}^{-1}$ was assigned to $\mathrm{NaBO}_{4}$ instead of $\mathrm{NaO}_{2}$ [32]. A similar oxidation has previously been observed upon the infiltration of $\mathrm{LiBH}_{4}$ in SBA-15, and in this case, this led to the formation of $\mathrm{LiBO}_{2}$ [33]. Besides these oxidized phases, the peak observed at $2496 \mathrm{~cm}^{-1}$ was attributed to the formation of $\mathrm{Na}_{2} \mathrm{~B}_{12} \mathrm{H}_{12}$, which is commonly reported to occur upon a partial decomposition of $\mathrm{NaBH}_{4}[34,35]$. These results are also in agreement with the ${ }^{11} \mathrm{~B}$ NMR spectrum (Figure 3 ) showing the typical resonance of the $\mathrm{BH}_{4}{ }^{-}$anion centered at $-41.95 \mathrm{ppm} \mathrm{[36];} \mathrm{a} \mathrm{single} \mathrm{sharp} \mathrm{peak} \mathrm{at}-2 \mathrm{ppm}$, assigned to boron in tetrahedral $\mathrm{BO}_{4}$ environments [37]; and at $-15.58 \mathrm{ppm}$, a peak corresponding to the dodecahedral $\left[\mathrm{B}_{12} \mathrm{H}_{12}\right]^{2-}$ anion in $\mathrm{Na}_{2} \mathrm{~B}_{12} \mathrm{H}_{12}$ [38].
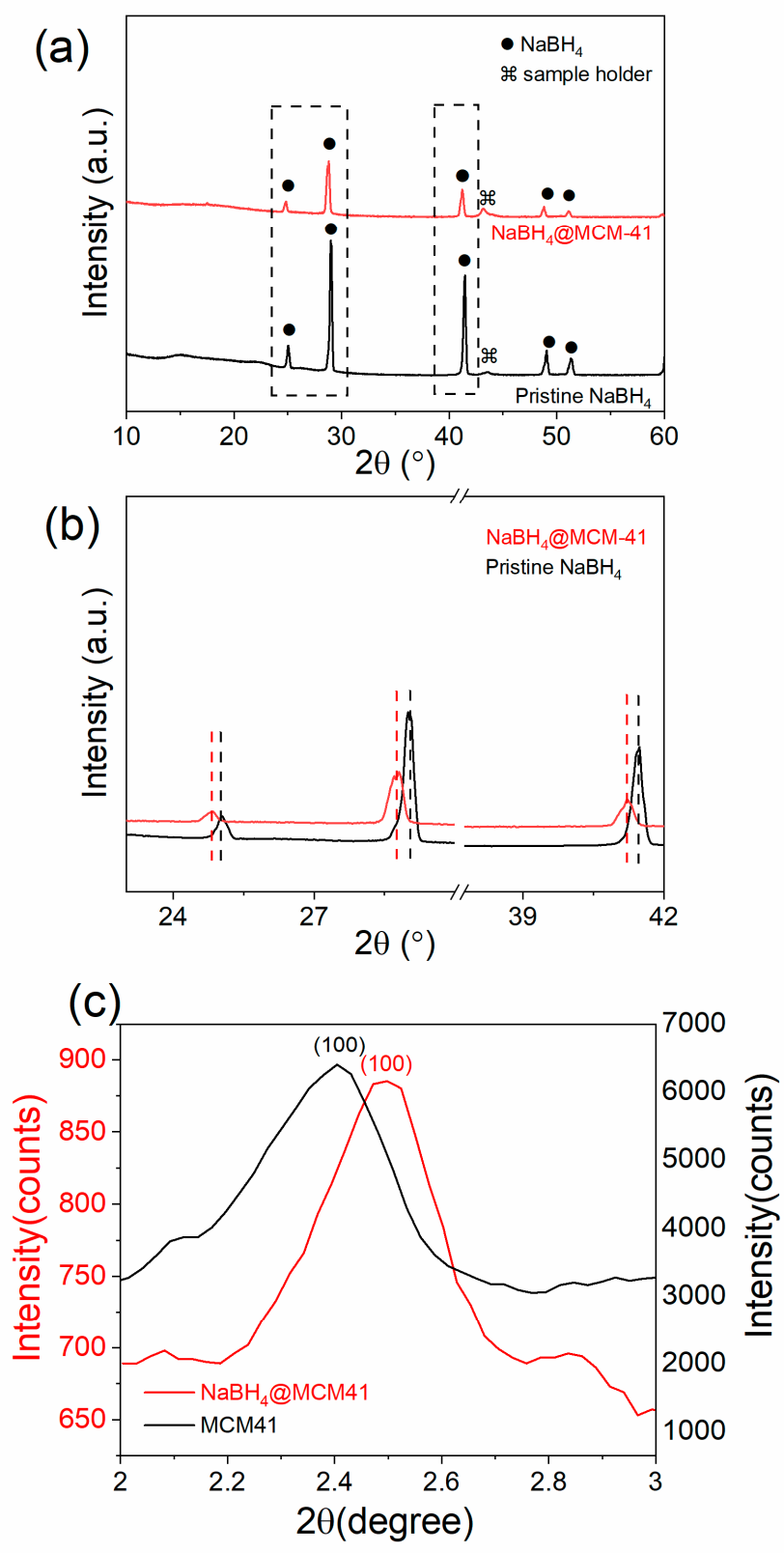

Figure 1. (a) X-ray diffraction (XRD) of nanoconfined $\mathrm{NaBH}_{4}$ along with that of pristine $\mathrm{NaBH}_{4}$ and (b) magnification of (a) for $2 \theta=23-42^{\circ}$; (c) small angle XRD of MCM-41 and $\mathrm{NaBH}_{4} @ \mathrm{MCM}-41$. 


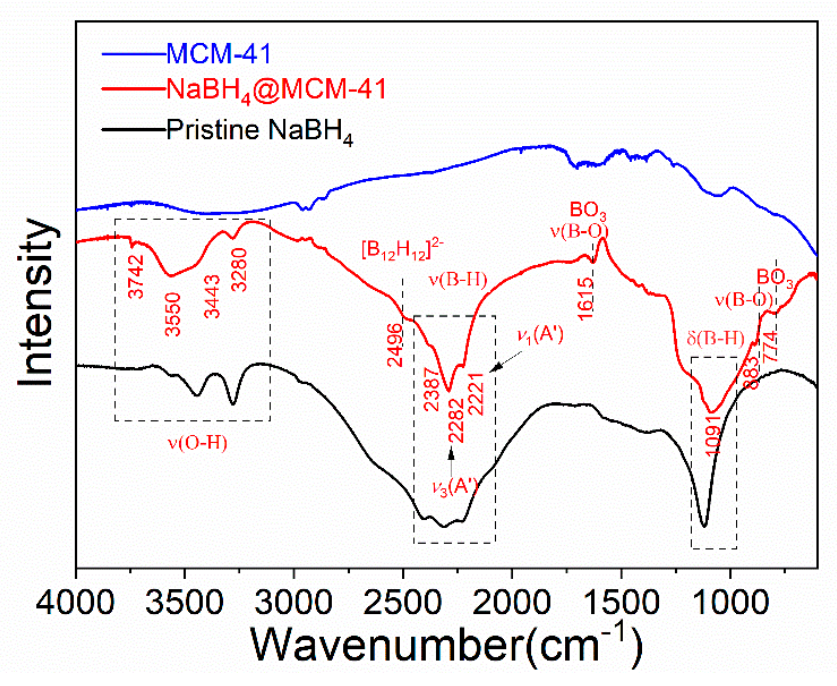

Figure 2. FTIR analysis of $\mathrm{NaBH}_{4} @ \mathrm{MCM}-41$ and pristine $\mathrm{NaBH}_{4}$.

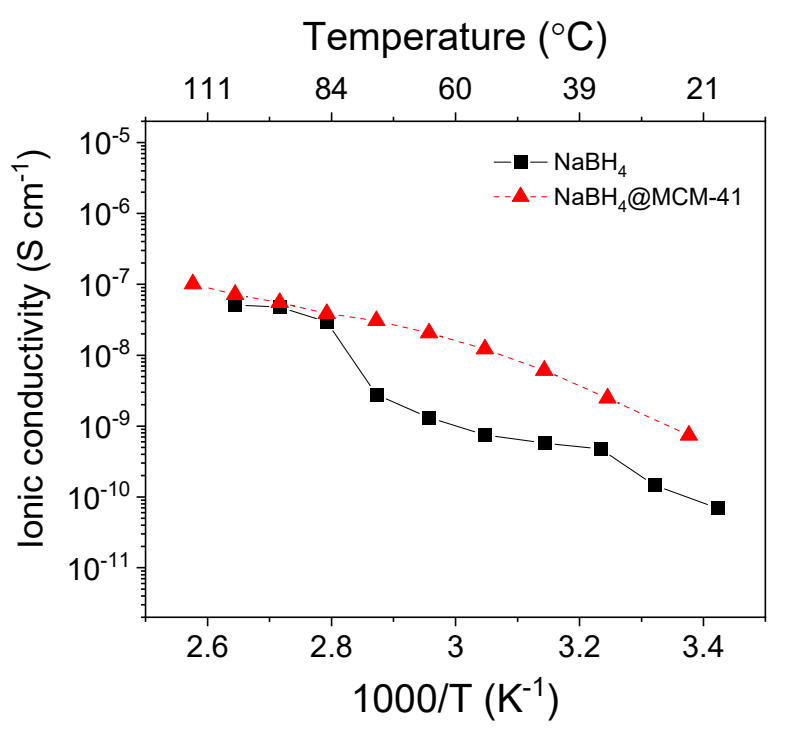

Figure 3. Arrhenius plot of $\mathrm{NaBH}_{4} @ \mathrm{MCM}-41$ and pristine $\mathrm{NaBH}_{4}$. The cause for the small "jump" in ionic conductivity for $\mathrm{NaBH}_{4}$ is unknown as it does not correspond to any known phase transition.

\subsection{Ionic Conductivity of Nanoconfined $\mathrm{NaBH}_{4}$}

The ionic conductivity of the pristine $\mathrm{NaBH}_{4}$ and $\mathrm{NaBH}_{4} @ \mathrm{MCM}-41$ was determined by electrochemical impedance spectroscopy (EIS) (Figure 3). The ionic conductivity of $\mathrm{NaBH}_{4} @ \mathrm{MCM}-41$ is 10 times higher (i.e., $7.4 \times 10^{-10} \mathrm{~S} \mathrm{~cm}^{-1}$ at $20^{\circ} \mathrm{C}$ ) than that of pristine $\mathrm{NaBH}_{4}$ in the temperature range of $20-70{ }^{\circ} \mathrm{C}$. However, above $70{ }^{\circ} \mathrm{C}$, the ionic conductivity of $\mathrm{NaBH}_{4}$ and $\mathrm{NaBH}_{4} @ \mathrm{MCM}-41$ was found to be of the same magnitude. To our surprise, encapsulating $\mathrm{NaBH}_{4}$ into MCM-41 did not significantly enhance the ionic conductivity. This may be because of the extensive reaction of nanoconfined $\mathrm{NaBH}_{4}$ with the walls of MCM-41 during melt infiltration, which resulted in the formation of an insulating oxide phase [39]. Indeed, boron oxide phases (e.g., $\mathrm{NaBO}_{4}$ ) have been reported to be poor ionic conductors [40]. In previous reports, it has been suggested that the ionic conductivity of MCM-41 nanoconfined $\mathrm{LiBH}_{4}$ was the result of the $\mathrm{LiBH}_{4} / \mathrm{MCM}-41$ interface promoting the reorientation of $\mathrm{BH}_{4}{ }^{-}[10,25]$. To verify this hypothesis, we reproduced the nanoconfinement of $\mathrm{LiBH}_{4}$ by melt infiltration in MCM-41 [10]. Successful nanoconfinement of $\mathrm{LiBH}_{4}$ was verified by BET and thermogravimetric analysis (TGA) and differential scanning calorimetry (DSC) analysis (Figures S5 and S6). In this case, the ionic conductivity 
of $\mathrm{LiBH}_{4} @ \mathrm{MCM}-41$ was found to be $1.34 \times 10^{-7} \mathrm{~S} \mathrm{~cm}^{-1}$ at $110{ }^{\circ} \mathrm{C}$ (Figure $\mathrm{S} 9$ ), which is four times lower in magnitude as compared with the reported value of $10^{-3} \mathrm{~S} \mathrm{~cm}^{-1}$ [10]. Through careful analysis by FTIR (Figure S7), strong B-O vibrations were observed in $\mathrm{LiBH}_{4} @ \mathrm{MCM}-41$ as compared with pristine $\mathrm{LiBH}_{4}$. These were assigned to lithium borates $\left(\mathrm{Li}_{2} \mathrm{~B}_{4} \mathrm{O}_{7}\right)$ [41], and indicated a strong oxidation of the borohydride phase during nanoconfinement. The discrepancy between the ionic conductivity of the current $\mathrm{LiBH}_{4} @ \mathrm{MCM}-41$ and reported data may thus be attributed to the extensive oxidation of the complex borohydride within the scaffold material. Here, we emphasize the inevitable reaction between the pore wall in MCM-41 and complex borohydrides and the resulting negative effect on ionic conduction.

One factor that may explain the increase in ionic conductivity observed for $\mathrm{NaBH}_{4} @ \mathrm{MCM}-41$ below $70{ }^{\circ} \mathrm{C}$ is the presence of $\mathrm{Na}_{2} \mathrm{~B}_{12} \mathrm{H}_{12}$, which was reported to lead to improved ionic conductivity [42]. Through integrating the chemical shifts of $\mathrm{B}_{12} \mathrm{H}_{12}$ located at $-15.6 \mathrm{ppm}$ in $\mathrm{NaBH}_{4} @ \mathrm{MCM}-41$ (Figure 4), $18 \%$ of amorphous $\mathrm{Na}_{2} \mathrm{~B}_{12} \mathrm{H}_{12}$ appeared in $\mathrm{NaBH}_{4} @ \mathrm{MCM}$ 41 owing to decomposition of $\mathrm{NaBH}_{4}$ (Figure 4). We believed that the appearance of the $\mathrm{Na}_{2} \mathrm{~B}_{12} \mathrm{H}_{12}$ in the nanoconfined material is due to the interaction between the $\mathrm{NaBH}_{4}$ and scaffold materials, triggering a partial decomposition of $\mathrm{NaBH}_{4}$ upon its oxidation and the release of $\mathrm{B}_{2} \mathrm{H}_{6}$, further reacting with $\mathrm{NaBH}_{4}$ to lead to $\mathrm{Na}_{2} \mathrm{~B}_{12} \mathrm{H}_{12}[43,44]$.

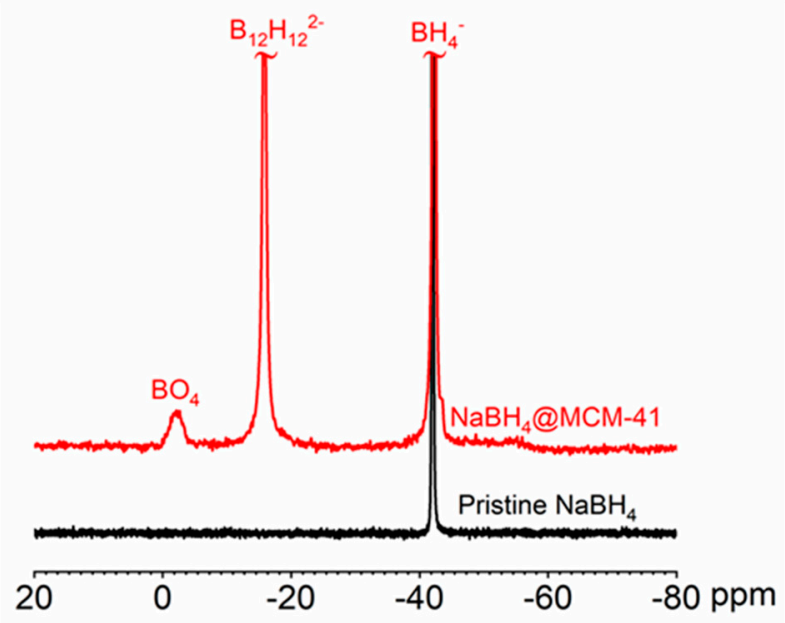

Figure 4. ${ }^{11} \mathrm{~B}$ nuclear magnetic resonance (NMR) of pristine $\mathrm{NaBH}_{4} @ \mathrm{MCM}-41$ and $\mathrm{NaBH}_{4}$.

To investigate if the presence of $\mathrm{Na}_{2} \mathrm{~B}_{12} \mathrm{H}_{12}$ within $\mathrm{NaBH}_{4}$ can effectively lead to improved ionic conductivities, we synthesised $\mathrm{NaBH}_{4}$ with higher amounts of $\mathrm{Na}_{2} \mathrm{~B}_{12} \mathrm{H}_{12}$. After the reaction between $\mathrm{B}_{2} \mathrm{H}_{6}$ and $\mathrm{NaBH}_{4}, 43 \%$ of the starting $\mathrm{NaBH}_{4}$ was converted to $\mathrm{Na}_{2} \mathrm{~B}_{12} \mathrm{H}_{12}$ (Figure S10). Such a mixture of $\mathrm{NaBH}_{4}$ and $\mathrm{Na}_{2} \mathrm{~B}_{12} \mathrm{H}_{12}$ is stable up to $300{ }^{\circ} \mathrm{C}$ (Figure S11) and exhibited a drastic enhancement in ionic conductivity, with an ionic conductivity of $10^{-6} \mathrm{~S} \mathrm{~cm}^{-1}$ at $110^{\circ} \mathrm{C}$ (Figure 5). This is two magnitudes higher than pristine $\mathrm{NaBH}_{4}$ [45]. Thus, the enhancement in ionic conductivity observed in nanoconfined $\mathrm{NaBH}_{4} @ \mathrm{MCM}-41$ can be assigned to the existence of the $\mathrm{B}_{12} \mathrm{H}_{12}{ }^{2-}$ anion. Anion rotation is believed to significantly enhance cation hopping [46,47], and $\mathrm{B}_{12} \mathrm{H}_{12}{ }^{-}$exhibits an intrinsically high dynamic motion [48]. Accordingly, the enhanced ionic conductivity in $\mathrm{NaBH}_{4} @ \mathrm{MCM}-41$ was attributed to the co-existence of $\mathrm{B}_{12} \mathrm{H}_{12}{ }^{2-}$ and $\mathrm{BH}_{4}{ }^{-}$. We thus believe that fine tuning the ratio between $\mathrm{Na}_{2} \mathrm{~B}_{12} \mathrm{H}_{12}$ and $\mathrm{NaBH}_{4}$ will further increase the ionic conductivity of $\mathrm{NaBH}_{4}$ and other complex borohydrides. Further investigations along this path are underway. 


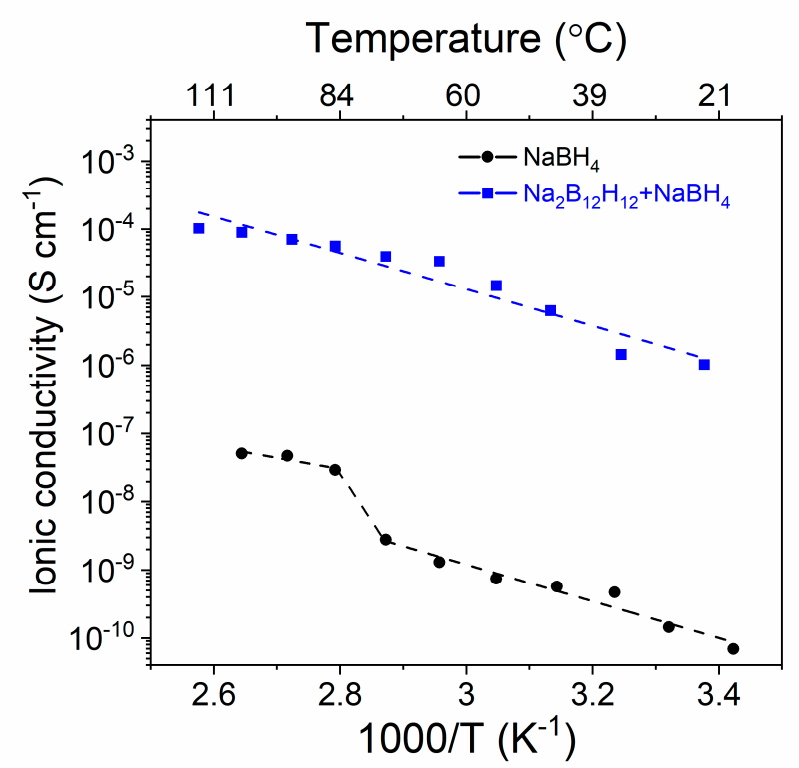

Figure 5. Arrhenius plot of $\mathrm{NaBH}_{4}$ and the $\mathrm{NaBH}_{4}+\mathrm{Na}_{2} \mathrm{~B}_{12} \mathrm{H}_{12}$ composite synthesised by exposing $\mathrm{NaBH}_{4}$ to $\mathrm{B}_{2} \mathrm{H}_{6}$.

\section{Materials and Methods}

\subsection{Synthesis}

All the operations were carried out under an inert atmosphere in an argon-filled LCTechnology glove box (<1 ppm $\mathrm{O}_{2}$ and $\mathrm{H}_{2} \mathrm{O}$, Salisbury, MA, USA). Sodium borohydride $\left(\mathrm{NaBH}_{4}, 99 \%\right)$ was purchased from Sigma-Aldrich (Sydney, NSW, Australia) and further purified. $\mathrm{ZnCl}_{2}(\geq 98 \%$ ) was purchased from Ajax Finechemn (Sydney, NSW, Australia), and dried at $120{ }^{\circ} \mathrm{C}$ overnight on a Schlenk line under vacuum (0.01 MPa) before use. Lithium borohydride $\left(\mathrm{LiBH}_{4}, 95 \%\right.$ ) was purchased from Acros (Sydney, NSW, Australia). Prior to use, $\mathrm{LiBH}_{4}$ was purified following the reported procedures [49]. MCM-41 was purchased from ACS materials and dried under vacuum at $200{ }^{\circ} \mathrm{C}$ for $2 \mathrm{~h}$ before use to remove any water traces.

\subsubsection{Synthesis of the Nanoconfined Complex Borohydrides}

For the nanoconfinement of $\mathrm{NaBH}_{4}$ into MCM-41 (noted $\mathrm{NaBH}_{4} @ \mathrm{MCM}-41$ ), a mixture of $1.5 \mathrm{~g} \mathrm{NaBH}_{4}$ grinded with $1.27 \mathrm{~g} \mathrm{MCM}-41$ was heated at $5{ }^{\circ} \mathrm{C} \mathrm{min}^{-1}$ and kept at $560{ }^{\circ} \mathrm{C}$ for $3.5 \mathrm{~h}$ under $8 \mathrm{MPa} \mathrm{H}$ pressure. This temperature was chosen because $\mathrm{NaBH}_{4} \mathrm{melts}$ at $500{ }^{\circ} \mathrm{C}$ (Figure S4)

$\mathrm{LiBH}_{4} @ \mathrm{MCM}-41$ was synthesized as per previous report [10]. $\mathrm{LiBH}_{4}$ infiltration was carried out to fill $100 \%$ of the pore volume of MCM-41. This was achieved by mixing $0.85 \mathrm{~g}$ of $\mathrm{LiBH}_{4}$ with $0.127 \mathrm{~g}$ of MCM-41 in a mortar and pestle. The mixture was then placed in a stainless-steel sample holder and heated to $295^{\circ} \mathrm{C}$ at $5{ }^{\circ} \mathrm{C} \mathrm{min}{ }^{-1}$ under an $\mathrm{H}_{2}$ pressure of $10 \mathrm{MPa}$. Infiltration was done at this temperature for $30 \mathrm{~min}$.

\subsubsection{Synthesis of the Mixture of $\mathrm{NaBH}_{4}$ and $\mathrm{Na}_{2} \mathrm{~B}_{12} \mathrm{H}_{12}$ Was via Solid-Gas Reaction}

$\mathrm{NaZn}_{2}\left(\mathrm{BH}_{4}\right)_{5}$ was synthesised by ball milling pristine $\mathrm{NaBH}_{4}$ and $\mathrm{ZnCl}_{2}$ with a molar ratio of 2:1 with a Retsch MM301 mill operated at a frequency of $20 \mathrm{~Hz}$. The mixture of $\mathrm{NaBH}_{4}$ and $\mathrm{ZnCl}_{2}$ was milled in a stainless-steel vial $(25 \mathrm{~mL})$ containing a single stainlesssteel ball (15 mm diameter) for $10 \mathrm{~min}$. Sodium borohydride (120 mg) was ball-milled in a similar manner under high purity argon in a $15 \mathrm{~mL}$ stainless steel vial filled with a single stainless-steel ball (1.5 $\mathrm{g}$ and $15 \mathrm{~mm}$ diameter).

The synthesis of $\mathrm{NaBH}_{4} / \mathrm{Na}_{2} \mathrm{~B}_{12} \mathrm{H}_{12}$ mixed compounds was undertaken in an in-house built Sievert apparatus with a customized sample holder, which had two compartments separated by a stainless-steel mesh (20 $\mu \mathrm{m}$ porosity). Then, $100 \mathrm{mg}$ of ball milled $\mathrm{NaBH}_{4}$ 
was placed on the top of the mesh and $400 \mathrm{mg} \mathrm{NaZn}{ }_{2}\left(\mathrm{BH}_{4}\right)_{5}$ was placed at the bottom of the sample holder. The reaction was carried out at $150{ }^{\circ} \mathrm{C}$ for $4 \mathrm{~h}$ under $10 \mathrm{MPa} \mathrm{H}_{2}$. The materials synthesized by this solid-gas reaction were then ball milled in a $15 \mathrm{~mL}$ stainless steel vial filled with a single stainless steel ball (1.5 $\mathrm{g}$ and $15 \mathrm{~mm}$ diameter) at a frequency of $20 \mathrm{~Hz}$ for $10 \mathrm{~min}$, and the previous synthesis route was repeated to maximise the $\mathrm{Na}_{2} \mathrm{~B}_{12} \mathrm{H}_{12}$ yield.

\subsection{Characterization}

The crystalline nature of the materials was determined by X-ray diffraction (XRD) using a Philips X'pert Multipurpose XRD system (Bruker, Preston, Victoria, Australia)operated at $40 \mathrm{~mA}$ and $45 \mathrm{kV}$ with a monochromatic $\mathrm{Cu} \mathrm{K} \alpha$ radiation $(\lambda=1.541 \AA)$-step size $=0.01^{\circ}$, time per step $=10 \mathrm{~s} \cdot \mathrm{step}^{-1}$. The materials were protected against oxidation from the air by a Kapton foil.

Infrared analysis was carried out on a Bruker Vertex $70 \mathrm{~V}$ (Bruker, Preston, Victoria, Australia) equipped with a Harrick diffuse reflectance Praying Mantis accessory. The materials were loaded in an air-tight chamber in the glovebox and the chamber was fitted on the Praying Mantis. Spectra were acquired with a $1 \mathrm{~cm}^{-1}$ resolution with an MCT-detector.

Solid-state ${ }^{11} \mathrm{~B}$ magic angle spinning (MAS) nuclear magnetic resonance (NMR) experiments were carried out on a narrow-bore Bruker Biospin Avance III solids-700 MHz spectrometer (Bruker, Preston, Victoria, Australia) with a 16.4 Tesla superconducting magnet operating at a frequency of $224.7 \mathrm{MHz}{ }^{11} \mathrm{~B}$ nucleus. Approximately 3-10 $\mathrm{mg}$ of material was packed into $4 \mathrm{~mm}$ zirconia rotors fitted with Kel- $\mathrm{f}^{\circledR}$ caps or vespel caps, respectively. The $4 \mathrm{~mm}$ rotors were spun in a double resonance $\mathrm{H}-\mathrm{X}$ probe head at $14 \mathrm{kHz}$ at the magic angle. The ${ }^{11} \mathrm{~B}$ spectra were acquired with hard 1 to $3 \mu$ s radio frequency pulses corresponding to a $30^{\circ}$ tip angle. The recycle delays of up to $10 \mathrm{~s}$ were used to ensure full relaxation of the signals of all nuclei, and up to 512 transients were co-added to ensure sufficient signal to noise. The spectra were obtained at room temperature and chemical shifts were referenced using a $1 \mathrm{M} \mathrm{NaCl}_{(\mathrm{aq})}$ for ${ }^{23} \mathrm{Na}, \mathrm{NaBH}_{4(\mathrm{~s})}$ for ${ }^{11} \mathrm{~B}$, and $1 \mathrm{M} \mathrm{LiCl}_{(\mathrm{aq})}$ for ${ }^{7} \mathrm{Li}$. The spectral deconvolution was carried out using the Dmfit software [50].

Thermogravimetric analysis (TGA) and differential scanning calorimetry (DSC) in conjunction with mass spectrometry (MS) were conducted at $10^{\circ} \mathrm{C} \mathrm{min}$ min $^{-1}$ under an argon flow of $20 \mathrm{~mL} \mathrm{~min}^{-1}$ using a Mettler Toledo TGA/DSC 3 (Mettler Toledo, Melbourne, Victoria, Australia) coupled with an Omnistar (Pfeiffer) MS. Masses between $\mathrm{m} / \mathrm{z}=2$ and 100 were followed and $40 \mu \mathrm{L}$ alumina crucibles were used.

The MCM-41 and nanoconfined $\mathrm{NaBH}_{4}$ morphology and elemental mapping were determined by transmission electron microscopy (TEM) and scanning transmission electron microscopy (STEM) using a Philips CM200 (Philips, Eindhoven, Netherlands) operated at $200 \mathrm{kV}$. For TEM analysis, the materials were ground and dispersed in cyclohexane, sonicated for a few seconds, and then dropped onto a carbon coated copper grid. BrunauerEmmett-Teller (BET) was performed using a Micromeritics TriStar 3000 Analyzer from Micrometrics Instrument Corporation (Norcross, GA, USA).

The ionic conductivity of the materials was determined by electrochemical impedance spectroscopy (EIS) (Biologic, Sydney, NSW, Australia). Here, $30 \mathrm{mg}$ of materials was placed in a $10 \mathrm{~mm}$ diameter die and uniaxially cold pressed at $9 \mathrm{MPa}$ with a hydraulic press to make a pellet of $0.03 \mathrm{~cm}$ thickness and $0.712 \mathrm{~cm}^{2}$. Two polished sheets of stainless steel were used as electrodes. The pellet was then placed into a controlled environment sample holder (CESH) from BioLogic (Biologic, Sydney, NSW, Australia). The cell was assembled in the glove box under argon atmosphere. EIS was conducted using an alternating current impedance spectroscopy method with a VMP3 potentiostat from BioLogic. The AC impedance measurement was set from $100 \mathrm{mHz}$ to $1 \mathrm{MHz}$. The measurement was conducted in the temperature range from 25 to $135{ }^{\circ} \mathrm{C}$ with an interval of $10^{\circ} \mathrm{C}$. Before each measurement, the sample dwelled for $20 \mathrm{~min}$ for temperature equilibration. 


\section{Conclusions}

In conclusion, we encapsulated $\mathrm{NaBH}_{4}$ into MCM-41 and the resulting $\mathrm{NaBH}_{4} @ \mathrm{MCM}$ 41 material was expected to lead to higher $\mathrm{Na}^{+}$ionic conductivities. However, any enhancement in ionic conductivity was found to be hindered by the formation of oxide phases in $\mathrm{NaBH}_{4} @ \mathrm{MCM}-41$, and similar observations made with $\mathrm{LiBH}_{4} @ \mathrm{MCM}-41$ tend to prove this hypothesis. We thus propose that the inevitable oxidation between complex borohydrides and MCM-41 may have a negative effect on the ionic conductivity. However, the presence of the large cage-like anions $\left(\mathrm{B}_{12} \mathrm{H}_{12}\right)^{2-}$ formed upon the partial decomposition of the borohydrides during their nanoconfinement may lead to a more effective path to improve their ionic conductivity.

Supplementary Materials: The following are available online at https:/ /www.mdpi.com/2304-6 740/9/1/2/s1, Figure S1: BET analysis for MCM-41 and $\mathrm{NaBH}_{4} @ M C M-41$ : (a) $\mathrm{N}_{2}$ physisorption and (b) pore size distribution; Figure S2: Typical TEM image of (a) the empty scaffold MCM-41 and (b) $\mathrm{NaBH}_{4} @ M C M-41$; Figure S3: STEM elemental mapping of $\mathrm{NaBH}_{4} @ M C M-41$; Figure S4: TGA-DSC-MS profiles of (a) pristine $\mathrm{NaBH}_{4}$ and (b) $\mathrm{NaBH}_{4} @ M C M-41$; Figure S5: BET analysis for MCM-41 and $\mathrm{LiBH}_{4} @ \mathrm{MCM}-41$ : (a) $\mathrm{N}_{2}$-physisorption and (b) pore size distribution; Figure S6: TGA-DSC-MS profiles of (a) pristine $\mathrm{LiBH}_{4}$ and (b) $\mathrm{LiBH}_{4} @ \mathrm{MCM}-41$; Figure S7: FTIR analysis of $\mathrm{LiBH}_{4} @ \mathrm{MCM}-41$ and pristine $\mathrm{LiBH}_{4}$; Figure S8: FTIR analysis of $\mathrm{NaBH}_{4} @ \mathrm{MCM}-41$ and pristine $\mathrm{NaBH}_{4}$; Figure S9: Arrhenius plot of $\mathrm{LiBH}_{4} @ \mathrm{MCM}-41$ and pristine $\mathrm{LiBH}_{4}$; Figure S10: ${ }^{11} \mathrm{~B}$ NMR of the $\mathrm{NaBH}_{4}+\mathrm{Na}_{2} \mathrm{~B}_{12} \mathrm{H}_{12}$ composite synthesised by exposing $\mathrm{NaBH}_{4}$ to $\mathrm{B}_{2} \mathrm{H}_{6}$; Figure S11: Arrhenius plot of $\mathrm{NaBH}_{4}$ and the $\mathrm{NaBH}_{4}+\mathrm{Na}_{2} \mathrm{~B}_{12} \mathrm{H}_{12}$ composite synthesised by exposing $\mathrm{NaBH}_{4}$ to $\mathrm{B}_{2} \mathrm{H}_{6}$; Table S1: Summary of BET analysis for MCM-41, $\mathrm{NaBH}_{4} @ \mathrm{MCM}-41$, and LiBH4@MCM-41.

Author Contributions: X.L. performed the research and analyzed the data. A.R. and K.-F.A.-Z. conceived and supervised the work, and analyzed the data. All authors have read and agreed to the published version of the manuscript.

Funding: We acknowledge support from the UNSW Digital Grid Futures Institute, UNSW Sydney, under a cross-disciplinary fund scheme and the ARC Research Hub on Integrated Energy Storage solutions.

Institutional Review Board Statement: Not applicable.

Informed Consent Statement: Not applicable.

Data Availability Statement: Not applicable

Conflicts of Interest: The authors declare no conflict of interest.

\section{References}

1. Bachman, J.C.; Muy, S.; Grimaud, A.; Chang, H.-H.; Pour, N.; Lux, S.F.; Paschos, O.; Maglia, F.; Lupart, S.; Lamp, P.; et al. Inorganic solid-state electrolytes for lithium batteries: Mechanisms and properties governing ion conduction. Chem. Rev. 2016, 116, 140-162. [CrossRef] [PubMed]

2. Zhao, C.; Liu, L.; Qi, X.; Lu, Y.; Wu, F.; Zhao, J.; Yu, Y.; Hu, Y.-S.; Chen, L. Solid-State Sodium Batteries. Adv. Energy Mater. 2018, 8, 1703012. [CrossRef]

3. Adachi, G.-Y.; Imanaka, N.; Tamura, S. Ionic Conducting Lanthanide Oxides. Chem. Rev. 2002, 102, 2405-2430. [CrossRef] [PubMed]

4. Nie, K.; Hong, Y.; Qiu, J.; Li, Q.; Yu, X.; Li, H.; Chen, L. Interfaces between Cathode and Electrolyte in Solid State Lithium Batteries: Challenges and Perspectives. Front. Chem. 2018, 6, 616. [CrossRef] [PubMed]

5. Kato, Y.; Hori, S.; Saito, T.; Suzuki, K.; Hirayama, M.; Mitsui, A.; Yonemura, M.; Iba, H.; Kanno, R. High-power all-solid-state batteries using sulfide superionic conductors. Nat. Energy 2016, 1, 16030. [CrossRef]

6. Sakuda, A.; Hayashi, A.; Tatsumisago, M. Sulfide Solid Electrolyte with Favorable Mechanical Property for All-Solid-State Lithium Battery. Sci. Rep. 2013, 3, 2261. [CrossRef]

7. Kim, J.-J.; Yoon, K.; Park, I.; Kang, K. Progress in the Development of Sodium-Ion Solid Electrolytes. Small Methods 2017, 1, 1700219. [CrossRef]

8. Chi, X.; Liang, Y.; Hao, F.; Zhang, Y.; Whiteley, J.; Dong, H.; Hu, P.; Lee, S.; Yao, Y. Tailored Organic Electrode Material Compatible with Sulfide Electrolyte for Stable All-Solid-State Sodium Batteries. Angew. Chem. Int. Ed. 2018, 57, 2630-2634. [CrossRef]

9. Lu, Z; Ciucci, F. Metal Borohydrides as Electrolytes for Solid-State Li, Na, Mg, and Ca Batteries: A First-Principles Study. Chem. Mater. 2017, 29, 9308-9319. [CrossRef] 
10. Blanchard, D.; Nale, A.; Sveinbjörnsson, D.; Eggenhuisen, T.M.; Verkuijlen, M.H.; Suwarno; Vegge, T.; Kentgens, A.P.M.; de Jongh, P.E. Nanoconfined $\mathrm{LiBH}_{4}$ as a Fast Lithium Ion Conductor. Adv. Funct. Mater. 2015, 25, 184-192. [CrossRef]

11. Matsuo, M.; Kuromoto, S.; Sato, T.; Oguchi, H.; Takamura, H.; Orimo, S.-I. Sodium ionic conduction in complex hydrides with $\left[\mathrm{BH}_{4}\right]^{-}$and $\left[\mathrm{NH}_{2}\right]^{-}$anions. Appl. Phys. Lett. 2012, 100, 203904. [CrossRef]

12. Matsuo, M.; Takamura, H.; Maekawa, H.; Li, H.-W.; Orimo, S.-I. Stabilization of lithium superionic conduction phase and enhancement of conductivity of $\mathrm{LiBH}_{4}$ by LiCl addition. Appl. Phys. Lett. 2009, 94, 084103. [CrossRef]

13. Gulino, V.; Brighi, M.; Dematteis, E.M.; Murgia, F.; Nervi, C.; Černý, R.; Baricco, M. Phase Stability and Fast Ion Conductivity in the Hexagonal $\mathrm{LiBH}_{4}-\mathrm{LiBr}-\mathrm{LiCl}$ Solid Solution. Chem. Mater. 2019, 31, 5133-5144. [CrossRef]

14. Verkuijlen, M.H.W.; Ngene, P.; de Kort, D.W.; Barré, C.; Nale, A.; van Eck, E.R.H.; van Bentum, P.J.M.; de Jongh, P.E.; Kentgens, A.P.M. Nanoconfined $\mathrm{LiBH}_{4}$ and Enhanced Mobility of $\mathrm{Li}^{+}$and $\mathrm{BH}_{4}{ }^{-}$Studied by Solid-State NMR. J. Phys. Chem. C 2012, 116, 22169-22178. [CrossRef]

15. Lambregts, S.F.H.; van Eck, E.R.H.; Suwarno; Ngene, P.; de Jongh, P.E.; Kentgens, A.P.M. Phase Behavior and Ion Dynamics of Nanoconfined $\mathrm{LiBH}_{4}$ in Silica. J. Phys. Chem. C 2019, 123, 25559-25569. [CrossRef]

16. Cuan, J.; Zhou, Y.; Zhou, T.; Ling, S.; Rui, K.; Guo, Z.; Liu, H.; Yu, X. Borohydride-Scaffolded Li/Na/Mg Fast Ionic Conductors for Promising Solid-State Electrolytes. Adv. Mater. 2019, 31, 1803533. [CrossRef]

17. Das, S.; Ngene, P.; Norby, P.; Vegge, T.; de Jongh, P.E.; Blanchard, D. All-Solid-State Lithium-Sulfur Battery Based on a Nanoconfined $\mathrm{LiBH}_{4}$ Electrolyte. J. Electrochem. Soc. 2016, 163, A2029-A2034. [CrossRef]

18. Kinoshita, S.; Okuda, K.; Machida, N.; Naito, M.; Sigematsu, T. All-solid-state lithium battery with sulfur/carbon composites as positive electrode materials. Solid State Ion. 2014, 256, 97-102. [CrossRef]

19. Wang, Z.; Zhou, L.; Lou, X.W. Metal Oxide Hollow Nanostructures for Lithium-ion Batteries. Adv. Mater. 2012, $24,1903-1911$. [CrossRef]

20. Thapaliya, B.P.; Do-Thanh, C.-L.; Jafta, C.J.; Tao, R.; Lyu, H.; Borisevich, A.Y.; Yang, S.-Z.; Sun, X.-G.; Dai, S. Simultaneously Boosting the Ionic Conductivity and Mechanical Strength of Polymer Gel Electrolyte Membranes by Confining Ionic Liquids into Hollow Silica Nanocavities. Batter. Supercaps 2019, 2, 985-991. [CrossRef]

21. Liu, Z.; Liu, P.; Tian, L.; Xiao, J.; Cui, R.; Liu, Z. Significantly enhancing the lithium-ion conductivity of solid-state electrolytes via a strategy for fabricating hollow metal-organic frameworks. Chem. Commun. 2020, 56, 14629-14632. [CrossRef] [PubMed]

22. Łodziana, Z.; Błoński, P. Structure of nanoconfined $\mathrm{LiBH}_{4}$ from first principles ${ }^{11} \mathrm{~B}$ NMR chemical shifts calculations. Int. J. Hydrogen Energy 2014, 39, 9842-9847. [CrossRef]

23. Remhof, A.; Mauron, P.; Züttel, A.; Embs, J.P.; Łodziana, Z.; Ramirez-Cuesta, A.J.; Ngene, P.; de Jongh, P. Hydrogen Dynamics in Nanoconfined Lithiumborohydride. J. Phys. Chem. C 2013, 117, 3789-3798. [CrossRef]

24. Wang, L.; Rawal, A.; Quadir, M.Z.; Aguey-Zinsou, K.-F. Nanoconfined lithium aluminium hydride $\left(\mathrm{LiAlH}_{4}\right)$ and hydrogen reversibility. Int. J. Hydrogen Energy 2017, 42, 14144-14153. [CrossRef]

25. Zettl, R.; de Kort, L.; Gombotz, M.; Wilkening, H.M.R.; de Jongh, P.E.; Ngene, P. Combined Effects of Anion Substitution and Nanoconfinement on the Ionic Conductivity of Li-Based Complex Hydrides. J. Phys. Chem. C 2020, 124, 2806-2816. [CrossRef]

26. Mihai, G.D.; Meynen, V.; Mertens, M.; Bilba, N.; Cool, P.; Vansant, E.F. ZnO nanoparticles supported on mesoporous MCM-41 and SBA-15: A comparative physicochemical and photocatalytic study. J. Mater. Sci. 2010, 45, 5786-5794. [CrossRef]

27. Gosalawit-Utke, R.; Suarez, K.; Bellosta von Colbe, J.M.; Bösenberg, U.; Jensen, T.R.; Cerenius, Y.; Bonatto Minella, C.; Pistidda C.; Barkhordarian, G.; Schulze, M.; et al. $\mathrm{Ca}\left(\mathrm{BH}_{4}\right)_{2}-\mathrm{MgF}_{2}$ Reversible Hydrogen Storage: Reaction Mechanisms and Kinetic Properties. J. Phys. Chem. C 2011, 115, 3762-3768. [CrossRef]

28. Landmesser, H.; Kosslick, H.; Storek, W.; Fricke, R. Interior surface hydroxyl groups in ordered mesoporous silicates. Solid State Ion. 1997, 101-103, 271-277. [CrossRef]

29. Jun, L.; Shuping, X.; Shiyang, G. FT-IR and Raman spectroscopic study of hydrated borates. Spectrochim. Acta Part A 1995, 51, 519-532. [CrossRef]

30. ElBatal, H.A.; Abdelghany, A.M.; ElBatal, F.H.; EzzElDin, F.M. Gamma rays interactions with $\mathrm{WO}_{3}{ }^{-}$doped lead borate glasses. Mater. Chem. Phys. 2012, 134, 542-548. [CrossRef]

31. Andrews, L.; Burkholder, T.R. Infrared spectra of molecular $\mathrm{B}(\mathrm{OH})_{3}$ and $\mathrm{HOBO}$ in solid argon. J. Chem. Phys. 1992, 97, 7203-7210. [CrossRef]

32. Ibrahim, M.L.; Nik Abdul Khalil, N.N.A.; Islam, A.; Rashid, U.; Ibrahim, S.F.; Sinar Mashuri, S.I.; Taufiq-Yap, Y.H. Preparation of $\mathrm{Na}_{2} \mathrm{O}$ supported CNTs nanocatalyst for efficient biodiesel production from waste-oil. Energy Convers. Manag. 2020, 205, 112445. [CrossRef]

33. Ngene, P.; Lambregts, S.F.H.; Blanchard, D.; Vegge, T.; Sharma, M.; Hagemann, H.; de Jongh, P.E. The influence of silica surface groups on the Li-ion conductivity of $\mathrm{LiBH}_{4} / \mathrm{SiO}_{2}$ nanocomposites. Phys. Chem. Chem. Phys. 2019, 21, 22456-22466. [CrossRef]

34. Mao, J.; Guo, Z.; Yu, X.; Liu, H. Improved Hydrogen Storage Properties of $\mathrm{NaBH} 4$ Destabilized by $\mathrm{CaH}_{2}$ and $\mathrm{Ca}\left(\mathrm{BH}_{4}\right)_{2}$. J. Phys. Chem. C 2011, 115, 9283-9290. [CrossRef]

35. Garroni, S.; Milanese, C.; Pottmaier, D.; Mulas, G.; Nolis, P.; Girella, A.; Caputo, R.; Olid, D.; Teixdor, F.; Baricco, M.; et al. Experimental Evidence of $\mathrm{Na}_{2}\left[\mathrm{~B}_{12} \mathrm{H}_{12}\right]$ and $\mathrm{Na}$ Formation in the Desorption Pathway of the $2 \mathrm{NaBH}_{4}+\mathrm{MgH}_{2} \mathrm{System}$. J. Phys. Chem. C 2011, 115, 16664-16671. [CrossRef]

36. Łodziana, Z.; Błoński, P.; Yan, Y.; Rentsch, D.; Remhof, A. NMR Chemical Shifts of ${ }^{11} \mathrm{~B}$ in Metal Borohydrides from First-Principle Calculations. J. Phys. Chem. C 2014, 118, 6594-6603. [CrossRef] 
37. Irwin, A.D.; Holmgren, J.S.; Jonas, J. Solid state ${ }^{29} \mathrm{Si}$ and ${ }^{11} \mathrm{~B}$ NMR studies of sol-gel derived borosilicates. J. Non-Cryst. Solids 1988, 101, 249-254. [CrossRef]

38. Hwang, S.-J.; Bowman, R.C.; Reiter, J.W.; Rijssenbeek; Soloveichik, G.L.; Zhao, J.-C.; Kabbour, H.; Ahn, C.C. NMR Confirmation for Formation of $\left[\mathrm{B}_{12} \mathrm{H}_{12}\right]^{2-}$ Complexes during Hydrogen Desorption from Metal Borohydrides. J. Phys. Chem. C 2008, 112, 3164-3169. [CrossRef]

39. Ngene, P.; Adelhelm, P.; Beale, A.M.; de Jong, K.P.; de Jongh, P.E. LiBH L $_{4}$ SBA-15 Nanocomposites Prepared by Melt Infiltration under Hydrogen Pressure: Synthesis and Hydrogen Sorption Properties. J. Phys. Chem. C 2010, 114, 6163-6168. [CrossRef]

40. Luo, X.; Rawal, A.; Cazorla, C.; Aguey-Zinsou, K.-F. Facile Self-Forming Superionic Conductors Based on Complex Borohydride Surface Oxidation. Adv. Sustain. Syst. 2020, 4, 1900113. [CrossRef]

41. Zhigadlo, N.D.; Zhang, M.; Salje, E.K.H. An infrared spectroscopic study of $\mathrm{Li}_{2} \mathrm{~B}_{4} \mathrm{O}_{7}$. J. Phys. Condens. Matter 2001, $13,6551-6561$. [CrossRef]

42. Sadikin, Y.; Brighi, M.; Schouwink, P.; Černý, R. Superionic conduction of sodium and lithium in anion-mixed hydroborates $\mathrm{Na}_{3} \mathrm{BH}_{4} \mathrm{~B}_{12} \mathrm{H}_{12}$ and $\left(\mathrm{Li}_{0.7} \mathrm{Na}_{0.3}\right)_{3} \mathrm{BH}_{4} \mathrm{~B}_{12} \mathrm{H}_{12}$. Adv. Energy Mater. 2015, 5, 1501016. [CrossRef]

43. Ngene, P.; van den Berg, R.; Verkuijlen, M.H.W.; de Jong, K.P.; de Jongh, P.E. Reversibility of the hydrogen desorption from $\mathrm{NaBH}_{4}$ by confinement in nanoporous carbon. Energy Environ. Sci. 2011, 4, 4108-4115. [CrossRef]

44. Caputo, R.; Garroni, S.; Olid, D.; Teixidor, F.; Surinach, S.; Baro, M.D. Can $\mathrm{Na}_{2}\left[\mathrm{~B}_{12} \mathrm{H}_{12}\right]$ be a decomposition product of NaBH $\mathrm{N}_{4}$ ? Phys. Chem. Chem. Phys. 2010, 12, 15093-15100. [CrossRef]

45. Udovic, T.J.; Matsuo, M.; Unemoto, A.; Verdal, N.; Stavila, V.; Skripov, A.V.; Rush, J.J.; Takamura, H.; Orimo, S.-i. Sodium superionic conduction in $\mathrm{Na}_{2} \mathrm{~B}_{12} \mathrm{H}_{12}$. Chem. Commun. 2014, 50, 3750-3752. [CrossRef] [PubMed]

46. Zhang, Z.; Li, H.; Kaup, K.; Zhou, L.; Roy, P.-N.; Nazar, L.F. Targeting Superionic Conductivity by Turning on Anion Rotation at Room Temperature in Fast Ion Conductors. Matter 2020, 2, 1667-1684. [CrossRef]

47. Zhang, Z.; Roy, P.-N.; Li, H.; Avdeev, M.; Nazar, L.F. Coupled Cation-Anion Dynamics Enhances Cation Mobility in RoomTemperature Superionic Solid-State Electrolytes. J. Am. Chem. Soc. 2019, 141, 19360-19372. [CrossRef] [PubMed]

48. Kweon, K.E.; Varley, J.B.; Shea, P.; Adelstein, N.; Mehta, P.; Heo, T.W.; Udovic, T.J.; Stavila, V.; Wood, B.C. Structural, Chemical, and Dynamical Frustration: Origins of Superionic Conductivity in closo-Borate Solid Electrolytes. Chem. Mater. 2017, 29, 9142-9153. [CrossRef]

49. Banfi, L.; Narisano, E.; Riva, R.; Baxter, E.W. Lithium borohydride. In Encyclopedia of Reagents for Organic Synthesis; John Wiley \& Sons: Hoboken, NJ, USA, 2005. [CrossRef]

50. Massiot, D.; Fayon, F.; Capron, M.; King, I.; Le Calvé, S.; Alonso, B.; Durand, J.-O.; Bujoli, B.; Gan, Z.; Hoatson, G. Modelling oneand two-dimensional solid-state NMR spectra. Magn. Reson. Chem. 2002, 40, 70-76. [CrossRef] 